\title{
Literacy: A Veritable Tool for Improving Livelihood in Nigeria
}

\author{
Zuofa, C.C. (Ph.D) \\ Department of Educational Foundations, Niger Delta University \\ Wilberforce Island, Bayelsa State, Nigeria \\ Tel: 234-803-340-3996 E-mail: zuofac@yahoo.com
}

Received: January 30, 2011 Accepted: March 15, 2011 doi:10.5539/ass.v7n8p159

\begin{abstract}
The concept "literacy" may seem very simple to the understanding of every individual, but it has proved to be complex, dynamic and continued to be defined and interpreted in various ways. Livelihood on the other hand, goes beyond poverty eradication and stretches to factors and processes that could enhance or hinder individual's ability to make a living. This paper gives a brief historical overview of literacy in Nigeria and clarified relevant concepts. It examined how literacy could be a veritable tool for improving livelihood. Some challenges were identified by the paper while advocating for increase in the provision of more relevant literacy programmes to affect livelihood as well as other literacy needs of the people.
\end{abstract}

Keywords: Literacy, Livelihood, Illiteracy and poverty

\section{Introduction}

It is globally acknowledged that poverty and illiteracy are linked together. Efforts at various levels by both government and non-governmental organisations and religious bodies to reduce and eliminate illiteracy are quite familiar in the Nigerian environment. Literacy efforts in Nigeria according to Nzeneri (2010) could be traced to $11^{\text {th }}$ century in the North by Muslim traders and teachers, as well as Christian missionaries who penetrated the southern part in the $16^{\text {th }}$ century. Later more Christian organisations dominated the south and established evening classes and Sunday schools for their converts, while Koranic and Arabic literacy dominated the north. In fact, the focus of literacy then was to enable converts read the religious literature and numerate members. It was the traditional literacy of reading, writing and arithmetic (the 3RS) that prevailed.

Other literacy efforts continued as noted by Ogili and Nzeneri (2001). For instance, the Udi Hill experiment in 1942 by Mr. E.R. Chadwick, the Mass education in Africa society's document published in 1943 which drew attention to adult literacy education in Nigeria. The mass education of 1946 with Major A.J. Carpenter as the first Mass Education Officer, who promoted literature in indigenous Nigeria languages.

Basic and functional literacy as well as formal education have continued to be encouraged in Nigeria by individuals, government and non-governmental organisations. But previous studies on provision of literacy in Nigeria reveal that it is in most cases limited to the illiterates, majority of which are women, the rural populace whose livelihood is mainly agrarian. The traditional men and women whose skills have been influenced by literacy programmes are in minority. Human needs increases and diversify each passing day as such new areas that require attention for literacy are emerging. The literacy need for Nigeria today especially for adults cannot be achieved by relying on formal educational system or sectional literacy. Moreso, complex changes are taking place in the world including Nigeria. Consequently, pattern of life and livelihood are influenced. For instance, policy research shows that the proportion of jobs that require technical training is on the increase. This means that the quality of human capital must be improved in order for individuals to be more productive for self and in the workplace. This certainly would have a multiplier effect on the nations' ability to compete effectively in the global economy.

On the other hand, educational needs of adults require provision which responds to their situation and could support them to develop their individual potentials in order to contribute to their immediate needs, communities, economically, socially, politically and otherwise. This makes it necessary for more forms of literacy to be introduced in Nigeria. The concern of this paper is therefore to advocate that more forms of literacy should be introduced to affect many areas of need and livelihood in Nigeria. 


\section{Conceptual Background}

Two concepts emerging from the topic need clarification for the purpose of this discussion, literacy and livelihood.

\subsection{Literacy}

Definitions of literacy abound. This prompted UNESCO (2006) to state that there are many definitions of literacy which nations, governments, organisations and individuals have advanced to suit their purpose and views. It cited a few countries and their concept about literacy. France (2005) for instance defined literacy as the ability to read and understand a simple text, and to use, and transmit written information for everyday life. For India, it is seen as the ability to read and write in any language. This is closely related to that of Nigeria where literacy means the ability to read, write in any language especially the local languages and simple calculation that can improve on-the-job performance, self help as well as development in the community.

Interestingly, UNESCO (2008) noted that literacy is not just the simple reading of words or a set of associated symbols and sounds, but an act of critical understanding of the situation in the world. It is not an end in itself, but a means of extending individual efforts towards education, involving overall inter-disciplinary responses to her/his problems. Literacy also leads to education which results to empowerment with acquisition of the essential knowledge and skills capable of making individuals engage in activities they require for effective functioning in self, group and community improvement.

Nzeneri (2010) apart from affirming that literacy means ability to read, write, communicate and compute figures that are involved in day-to-day activities, added that a literate adult is a person who can read and understand simple written and computed statements involved in everyday life. Consequently, the context of literacy as it relates to this paper goes beyond traditional and functional literacy to literacy that cuts across both literate and non-literate adults, youths and children irrespective of environment. The Federal Republic of Nigeria National Policy on Education (FRN, 2004) stated among others that the goals of Mass Literacy, Adult and Non-formal Education should provide functional literacy and continuing education for adults and youths who have never had the advantage of formal education or who did not complete their primary education. These include the nomads, migrant families, the disabled and other groups especially the disadvantaged gender. Functional literacy is planned specifically to meet the needs and challenges of learners thereby influencing their livelihood, but in Nigeria at the moment it is not diversified to meet new challenges.

\subsection{Livelihood}

Cobuild (2009) described livelihood as the job or other source of income that gives you the money to buy the things you need. In effect, the fishing job of a fisherman or woman as well as sale of vegetable and fruits from the garden make up cobuild description of livelihood. Krantz (2001) advanced that livelihood comprises the capabilities, assets (stores, resources claims and access) and activities required for a means of living.

Oxenharm, Diallo, Katahoire, Mwangi and Sall in their working papers to the World Bank defined livelihood in a traditional restricted sense as "making a living" which restricts itself to the knowledge, skills and methods used to produce or obtain the food, water, clothing and shelter necessary for survival and well-being. They observed that in Africa, most of the people who require basic literacy derived their living mainly from subsistence agriculture and often from the exchange of goods and services, rather than from earning wages or salaries. They however added that a livelihood can include more than one set of knowledge, skills and methods. An example can be cited in an agrarian economy where a woman may earn her family's livelihood by combining subsistence agriculture and horticulture on a small plot of land with remunerated labour on a neighbour's land and with selling some of her produce as processed food in a local market. This obviously portrays a typical Nigerian rural environment, where especially the women are engaged in subsistence farming or fishing depending on the terrain. They, at the same time are involved in processing their produce like cassava into "garri" or yam into "amala" and at the same time a petty trader in order to meet up with family livelihood. The issue here is how more literacy could be introduced to improve livelihood in Nigeria. The literacy provision presented by both government and non-government organisations seems not adequate for the teaming Nigeria populace.

\section{Literacy: A Veritable Tool for Livelihood}

Literacy has the ability of meeting up of specific learning needs and challenges of the participants or the learners in that the acquired literacy skills are immediately applied to improve their livelihood. This is further supported by World Bank (2002) view that people who had completed literacy courses tended to be more willing to take initiatives in developing their livelihoods or in taking an active interest in the operations of their cooperatives. 
Farmers have been observed by international organisations like Food Agricultural Organisation (FAO), International Fund for Agricultural Development (IFAD), International Labour Organisation (ILO) and supported effective integration of literacy and livelihood in many African countries with satisfactory outcome.

Diallo (2001) noted that literacy and livelihood are closely entwined due to some close observations made in some African countries like Guinea, Uganda and Ghana. Other researchers also observed that without a sufficient mastery of basic literacy, learners are disadvantaged and possibilities to increase knowledge, skills and capacities are doubtful.

\subsection{Gains of Literacy}

The United Nations Educational and Cultural Organisations (UNESCO)(2006) observed that individuals with literacy and numeracy skills are more productive, understand family planning and enjoy better quality of life. Eldred (2008) also noted that literacy linked to particular job skills contributes to development of critical thinking and problem solving.

Ezimah (2004) emphasised that literacy is an essential ingredient for obtaining personal, community and societal development and growth. ILO (1994) while working on income generating activities for women in health development in Nigeria recommended that functional literacy should be utilised to increase impact of training in new skills and technologies. Prompted by this, Zuofa (2008) highlighted the gains of literacy in empowering women. She noted that those who benefited from literacy programmes were more confident, kept records and progressed in their economic activities

Literacy skills are not ends in themselves but need to serve purposes and practices that are relevant to their users. For instance it leads to education which results to empowerment with the acquisition of the essential knowledge and skills that make it possible for individuals to engage in activities they require for effective functioning in self, group community improvement and livelihood.

\subsection{Challenges}

Many international conference like EFA, the Fifth International Conference in Adult Education CONFINTEA V (1997), United Nations Literacy Decade (2003-2012), and General Campaign for Education (2004/2005) as well as studies revealed that illiteracy is still a scourge and the greatest obstacle in adult life. Governments, individuals and organisations have been making efforts to reduce it, but a lot still need to be done. The level of illiteracy for instance is still relatively high in Nigeria as shown in table 1 on page 13 where more than $50 \%$ of some states population is illiterate and this could go for all the states in Nigeria.

The illiteracy level in so many ways affect the people's livelihood, constraining their ability to utilise opportunities and prospects that could enhance them. There is the challenges of policy provision not being backed up with political will. This has resulted to poor or non implementation of available literacy education policy framework that could impact adult livelihood in Nigeria more meaningfully.

Inadequate funding is another challenge that has restricted the provision and sustenance of many literacy programmes that would have improved livelihood in Nigeria. Financial allocation to education in general has not been encouraging especially for literacy education. This has always posed challenge to facilitators and learners.

Instructional materials are hardly provided, where they do, not adequate in most cases for literacy programmes. Olaitan and Ali (1997) noted that instructional materials and resources are sources from which learners may turn and secure helpful information for the attainment of instructional objectives.

Attention is mostly given to fundamental literacy reading, writing and computing. Other forms of illiteracy frustrate many Nigerians including the literate ones. There are many illiterates when it comes to the use of internet, computer, application of fertilizer and use of modern tools and machinery, electronic gadgets and other technological provisions, in offices, public places and even homes. Using mobile phone and utilising the various devises is still a problem to many. The true situation is that every individual is illiterate in one form or another, but consideration is yet to be given to these areas.

Learners and facilitators are not adequately motivated and learning environment not properly catered for. Take for instance the issue of seats. In most adult centres in Nigeria, the learners sit on the same seats that are meant for their children in formal school which in most cases are uncomfortable for them. 


\section{Implications for Practice}

Literacy is imperative and relevant for growth and productivity for both providers and learners.

Current trends in both human and physical development can only be made available and practicable through the curriculum.

The traditional concept of group dynamics promotes learning for reasons related to personal growth rather than for materialistic needs.

Adults who missed an earlier opportunity to learn and could not perform certain functions are usually fascinated by their new ability not only to read and write but to perform other functions. For instance, an adult learns to use his or her cell phone (handset) is excited with the improved communication and contacts that could be made to enhance pattern of life as well as livelihood.

Twenty first century Nigerians require literacy provision that cuts across all cadres- literate and non literates, urban and rural dwellers as well as youths and children.

\section{Conclusion and Recommendations}

This work has discussed that literacy is the ability of an individual to read, write and compute, thereby being functional as an individual, in a group and in communal activities. Livelihood on the other hand is all sources of income that provide support for a living. Literacy as such is a veritable tool that is capable of meeting up with specific learning needs of individuals as well as other challenges.

Lack of political will has been identified as one of the major challenges which has given rise to low financial support and other provisions as well as inadequate policy implementation. It is envisaged that improvement in this area and adopting some motivational strategies would improve both provision and implementation of literacy programmes which invariably would encourage learners' participation and influence their livelihood.

Literacy programmes should be designed to cover the necessary livelihood of people instead of randomly coming up with unrelated literacy programmes. Concerted efforts should also be made by relevant bodies to meet up other literacy needs of the populace.

Adult learning environment should be improved especially space, lightening, seats and toilet system. Instructional materials should be provided and the facilitators encouraged by paying them regular allowances.

Organisations like UNDP, UNICEF, UNESCO, and others should be encouraged to fund more literacy programmes that are relevant to livelihood in Nigeria. Group cooperatives should be encouraged among learners, since learning in groups make more impact than learning individually.

There should also be proper integration of literacy programmes into livelihood so that there could be systematic connection between literacy and livelihood.

\section{References}

Cobuild, C. (2009). Advance Dictionary of English. United Kingdom: Harper Collins Publishers.

Diallo, A.H. (2001). Strengthening livelihoods with literacy: the Guinea case-vission I. Bonn: Institute of International Cooperation, German Adult Education Association (IIZ/DVV).

Eldred, J. (2008). Reading and writing a better world. CONVERGENCE, volume 41, Number 2-3. United Kingdom: International Council for Adult Education.

Ezimah, O.A. (2004). Knowing Adult Education, its Nature, Scope and Processes. Owerri: Springfield Publishers.

Federal Republic of Nigeria. (2004). The National Policy on Education. Yaba: NERDC Press.

International Labour Organisation (ILO) (1994). Nigeria Training of Rural Woman in Productive Work Skills: Project Findings and Recommendations. Geneva:ILO.

Krantz, L. (2001). The Sustainable Livelihood Approach to Poverty Reduction. Swedish International Development Cooperation Agency.

Nwangi, A.P. (2001). Strengthening livelihoods with literacy: The Kenya Case. J. Bonn: International Cooperation, German Adult Education Association (IIZ/DVV).

Nzeneri, I.S. (2010). Adults in Battle: Any Hope of Victory? An Inaugural Lecture. Port Harcourt: University Press. 
Ogili, E.E. \& Nzeneri, I.S. (2011). Mass Literacy Education Vision in Nigeria: A Mission of half hope. $1^{\text {st }}$ National Conference. Enugu. Pages 133-156.

Olaitan, S.O. and Ali, A. (1997). The Making of Curriculum and Evaluation. Onitsha: Cape Publishers International.

Oxenham,J., Diallo, A. Katahoire, A. Nwangi, A. and Sall, O. (2002). Skills and Literacy Training for Better Livelihoods. World Bank Report ext.worldbank.orglext/MDG/home.

UNESCO. (2006). Literacy for Life.EFA Global Report. Paris: UNESCO.

United Nations Education Scientific and Cultural Organisation (UNESCO). (2008). Relationship between Literacy Education and Development. [Online] Available: http:www2:unescobkk.org (26 ${ }^{\text {th }}$ Oct., 2007).

World Bank. (2002). Human Development Sectors African Region. [Online] Available: http:www.worldbank.org/afr/findings (13 ${ }^{\text {th }}$ Jun., 2001).

Zuofa, C.C. \& Igbo, R. (2009). Perceived Influence of Duration of Literacy on Economic Empowerment of Rural Women in Bayelsa and Imo States, Nigeria. European Journal of Social Sciences (EJSS), 8(1):17-20.

Table 1. Literacy situation in Some Selected States in Nigeria

\begin{tabular}{|l|l|l|l|l|}
\hline States & $\begin{array}{l}\text { Projected population 15 } \\
\text { years and above }\end{array}$ & Literates & Illiterates & $\begin{array}{l}\text { Percentage } \\
\text { illiterates } \\
\%\end{array}$ \\
\hline Adamawa & $1,133,498$ & 3383,931 & 795,105 & 70.1 \\
\hline Anambra & $2,748,822$ & $1,662,459$ & $1,186,363$ & 42.0 \\
\hline Borno & $2,614,308$ & 643,378 & $1,970,930$ & 75.4 \\
\hline Benue & $2,848,694$ & $1,332,058$ & 1516636 & 53.2 \\
\hline Bayelsa & $1,182,452$ & 705,448 & 477,004 & 40.3 \\
\hline Abia & $1,399,394$ & 565,101 & 834,293 & 60.0 \\
\hline Akwa Ibom & $2,334,538$ & $1,580,389$ & 754,139 & 32.3 \\
\hline Grand Total \% illiteracy rates & & & $53.3 \%$ \\
\hline
\end{tabular}

Source: EFA Report FME in Aderinoye 2008 and Nzeneri 2010 